\title{
電子線橋かけ型ポリ塩化ビニル被覆鋼板の 塗膜特性に及ぼすモノマー種の影響
}

\author{
増原 憲一*・輿石 謙二*2 ・森 浩治*2・福本 博光*2 \\ Effects of Kinds of Monomers on Film Properties \\ for Electron Beam Cross-linked Poly (vinyl chloride) Coated Steel Sheets \\ Ken-ichi Masuhara, Kenji Koshishi, Koji Mori and Hiromitsu Fukumoto
}

\begin{abstract}
Synopsis : Poly (vinyl chloride) (PVC) paints containing electron beam (EB) sensitive monomers were coated on steel sheets and baked and cross-linked by EB subsequently. Increase of film hardness for the EB cross-linked PVC coated steel sheets was investigated by the use of various monomers. As the amounts of monomer in film increased, the film hardness increased. In case of smaller equivalent of double bonds of monomer, higher film hardness value was obtained with smaller portions of monomer. Property balance between the film hardness and the bend formability depended upon kinds of monomers, and as the difference of solubility parameter for monomer from that of plasticizer decreased, the property balance improved. EB cross-linked PVC coated steel sheet containing 50phr trimethyol propane trimethacrylate (TMPTMA) had pencil hardness F and OT bend formability. From dynamic viscoelasticity of EB cross-linked PVC film, it is assumed that plasticized PVC and TMPTMA were in miscibility, and rigidity of film was obtained by the dense bridging PVC by TMPTMA.
\end{abstract}

Key words : electron beam cross-linking; poly (vinyl chloride) coated steel sheets; hardness; formability ; solubility parameter; monomer; dynamic viscoelasticity.

\section{1. 緒言}

ポリ塩化ビニル樹脂被覆鋼板（以下，塩ビ鋼板）は耐食 性, 耐候性に優れるため, 古くから屋根材, サイディング 材などの外装建材に用いられてきた。またソフトな外観， 優れた成形加工性を有することから，エンボス，印刷を付 与することによって内装建材, あるいはオーディオ，スト ーブなどの家電機器外板にも用いられている。

この塩ビ鋼板は塩ビフィルムを鋼板に積層する方法と塩 ビプラスチゾルを鋼板に塗装する方法で製造されているが, 後者については塩ビ樹脂中の可塑剂量が前者と同程度であ っても，ポリ塩化ビニルホモポリマーの可塑化が不均一で あるため, 前者に比べて塗膜硬度が低い欠点がある。この ため, 後者については可塑剤量を低減させるなどの対応が とられている。

ところで塩ビ樹脂に電子線感受性モノマー（以下，モ） マー）を配合し, 電子線橋かけすると耐熱性が向上するこ とが知られており, 既に電線被覆材に実用化されている1)。 これは電子線橋かけによって, 可塑化されたポリ塩化ビニ ルホモポリマーの運動性が束縛されるためであるが，塩ビ 樹脂の硬度を向上させるほどのモノマー量を配合したもの
ではない。

そこで本研究ではモノマーを配合した塩ビプラスチゾル を電子線橋かけして塩ビ鋼板の塗膜硬度の増大について検 討し, また塗膜硬度と曲げ加工性との関係に及ぼすモノマ 一種の影響について調査した。さらに電子線橋かけ反応に 関して検討を加えた。

\section{2. 実験方法}

\section{$2 \cdot 1$ 試料}

塩ビプラスチゾルはPVC (日本ゼオン (株) 製ゼオン G28) 100 重量部 (以下, PVC100に対する重量をphr (per hundred resin)で表す), 可塑剂(フタル酸ジーイソノニル, 以下DINP) $15 \mathrm{phr}$, 希釈可塑剤(トリメチルペンタンジオールモノイソ ブチレート, 以下TXIB) $30 \mathrm{phr}$, エポキシ化大豆油 (アデ カアーガス社製ADK Cizer O-130P) 2 phr, Ba-Zn系安定 剤(アデカアーガス社製MARK AC-111) $3 \mathrm{phr}, \mathrm{TiO}_{2}-\mathrm{DINP}$ ペースト $\left(\mathrm{TiO}_{2} / \mathrm{DINP}=25 / 10\right.$ (mass/mass) ) 40phrを配 合し,さらにモノマーを所定量配合して, 石川式擋找混練 機を用い30min混練した後, 包含している空気を除去するた め, $1 \mathrm{kPa}$ の減圧下で30min保持して作製した。 
塩ビ鋼板は電気带鉛めっき鋼板（板厚 $0.5 \mathrm{~mm}$, 亜鉛付着 量片面 $20 \mathrm{~g} / \mathrm{m}^{2}$ ) に塗布型クロメート処理 (クロム付着量 40 $\left.\mathrm{mg} / \mathrm{m}^{2}\right)$ を施し, アクリル変性エポキシ系樹脂プライマー を乾燥膜厚 $5 \sim 6 \mu \mathrm{m}$ になるようにバーコーターで塗布, 焼 き付け（到達板温 $230^{\circ} \mathrm{C} ， 60 \mathrm{~s} ） し ， さ ら に$ 塩ビプラスチゾ 儿を乾燥膜厚約 $120 \mu \mathrm{m}$ になるように,バーューターで塗布, 燒き付け（到達板温 $220^{\circ} \mathrm{C} ， 60 \mathrm{~s}$ ）して作製した。また塩ビ 塗膜単体（以下，塩ビフィルム）は電気亜鉛めっき鋼板表 面に直接, 塩ビプラスチゾルを塗布, 焼き付けし, 冷却後 鋼板から剝離して作製した。

モノマーとして用いたトリメチロールプロパントリメタ クリレート（以下，TMPTMA）およびポリエチレングリ コールジメタクリレート（以下， $\mathrm{nG}$ (nはエチレングリュー ル繰り返し数)）(以上，新中村化学工業(株)製）はいずれ も精製せずにそのまま用いた。

\section{$2 \cdot 2$ 電子線照射}

塩ビ鋼板および塩ビフィルム(この場合，フィルムを鋼 板から永離しない状態で用いた）は電子線照射装置（日新 八イボルテージ(株)製キュアトロン200-20-30）を用いて加 速電圧 $200 \mathrm{kV}$, 線量率 $250 \mathrm{kGy} / \mathrm{s}$ の照射条件で所定線量の電 子線を照射した（特記しない場合， $100 \mathrm{kGy}$ ）。

\section{$2 \cdot 3$ 超微小硬度計による押し込み硬度の測定および塩ビ 鋼板の鉛筆硬度の評価}

超微小硬度計による押し込み硬度は(株)島津製作所製ダ イナミック超微小硬度計DUT-50を用いて $20^{\circ} \mathrm{C} て ゙$ 測定した。

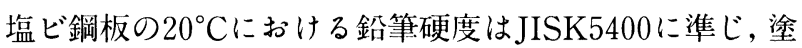
膜のすり傷から評価した。

\section{$2 \cdot 4$ フィルムの破断伸びの測定および塩ビ鋼板の曲げ加 工性の評価}

塩ビフィルムの破断伸びは(株)島津製作所製オートグラ フ AGS-100を用いて,チャック間隔40mm,クロスヘッド速 度 $0.83 \mathrm{~mm} / \mathrm{s}, 20^{\circ} \mathrm{C}$ 条件で短冊状塩ビフィルム (幅 $10 \mathrm{~mm} \times$ 長さ $60 \mathrm{~mm}$ ）の静的引つ張り試験により測定した。

塩ビ鋼板の $20^{\circ} \mathrm{Cにおける} 180^{\circ}$ 折り曲げ加工性は折り曲げ部 の内側に挟み込んだ試験板と同じ厚さの所定枚数nからnTで 表示し，加工部に割れが生じない最小鋼板枚数で評価した。

\section{$2 \cdot 5$ 焼き付け塗膜中の残存モノマー量の測定および熱重 量分析}

塩ビ塗膜の焼き付けに伴う残存モノマー量は, 焼き付け 後の塩ビフィルムをジエチルエーテルで $3 \mathrm{~h}$ 煮沸抽出し, 抽 出前後の重量減少量から可塑剤相当分 (可塑剤, エポキシ 化合物, 安定剤)を差し引いて, 樹脂100重量部当たりの重 量として求めた。

熱重量分析は (株)理学製熱重量分析装置を用いて，空気 中, 昇温速度 $0.33 \mathrm{~K} / \mathrm{s}$ の条件で, 室温から $300^{\circ} \mathrm{C}$ まで行った。 なお，モノマーについては昇温時の熱重合を抑制するため にヒドロキノンを 1 mass\%添加して分析した。

\section{$2 \cdot 6$ 赤外線分光分析および動的粘弾性の測定}

赤外吸収スペクトルは(株)島津製作所製IR-430を用いて, ATR法（KRS- 5 プリズム）により測定した。

動的粘弾性は東洋精機 (株) 製レオログラフソリッドを用 い, サンプルサイズ $8 \mathrm{~mm} \times 26 \mathrm{~mm}$, 昇温速度 $0.083 \mathrm{~K} / \mathrm{s}$, 周 波数 $10 \mathrm{~Hz}$ の条件で, $-50 \sim 150^{\circ} \mathrm{C}$ まで測定した。

\section{$2 \cdot 7$ 油性マーキングペンによる污染度の測定}

塩ビ鋼板表面に油性マーキングペン（マジックインキ） を塗り， $20^{\circ} \mathrm{C}, 24 \mathrm{~h}$ 静置後油性マーキングペンをエタノー

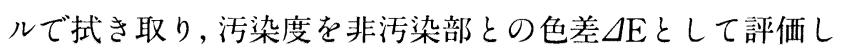
た2)。

$\Delta \mathrm{E}=\left((\Delta \mathrm{L})^{2}+(\Delta \mathrm{a})^{2}+(\Delta \mathrm{b})^{2}\right)^{1 / 2}$

L : Hunterの色差式における明度指数

$\mathrm{a}, \mathrm{b}$ ：Hunterの色差式におけるクロマネック齐ス指数

\section{3. 実験結果および考察}

\section{$3 \cdot 1$ 塗膜硬度, 破断伸びに及ぼすモノマー種の影響}

本研究では緒言でも述べたように，モノマーを橋かけ点 として，可塑化されたポリ塩化ビニルホモポリマーの運動 性を束縛し，塩ビ塗膜の剛性を上げることが目的である。 したがってモノマーはいずれも橋かけ点となる二重結合が 1 分子中に 2 個以上含まれるものを対象とした。それらを Table 1 に示寸。なお, 本研究ではモノマーの構造による影 響を検討するために，二重結合の反応性の違いをできるだ けなくすよう, 電子線感受性官能基である二重結合がメ夕 クリロイル基であるものに統一した。

Fig. 1 に塩ビプラスチゾル中へのモノマー配合量と塩ビ鋼 板の押し込み硬度との関倸を示す。モノマーが橋かけ点と なって塩ビ塗膜の剛性が増大すると考えると,Table 1 に示 した二重結合当量（分子量／二重結合数）が小さい方が少 ない配合量で高い押し込み硬度が得られるはずである。し かし, Fig. 1 の特性線において二重結合当量が最も小さい 1 $\mathrm{Gが} 2 \mathrm{G} ， 3 \mathrm{G}$ よも傾きが小さく，4 G と同程度であった。

Fig. 2 に塩ビプラスチゾル中へのモノマー配合量と塩ビ塗 膜中の残存モノマー量との関係を示す。nGについてnが小さ

Table 1. Equivalent of double bonds of monomers.

\begin{tabular}{cccc}
\hline & $\begin{array}{c}\text { number of } \\
\text { double bond }\end{array}$ & molecular weight & $\begin{array}{c}\text { equivalent of double } \\
\text { bonds of monomer }\end{array}$ \\
\hline TMPTMA & 3 & 338 & 113 \\
1G & 2 & 198 & 99 \\
2G & 2 & 242 & 121 \\
3G & 2 & 286 & 143 \\
$4 \mathrm{G}$ & 2 & 330 & 165 \\
$9 \mathrm{G}$ & 2 & 550 & 275 \\
\hline
\end{tabular}

TMPTMA : Trimethylol propane trimethacrylate

$1 G$ : Ethylene glycol dimethacrylate

2G: Diethylene glycol dimethacrylate

3G : Triethylene glycol dimethacrylate

4G: Tetraethylene glycol dimethacrylate

$9 \mathrm{G}$ : Nonaethylene glycol dimethacrylate 


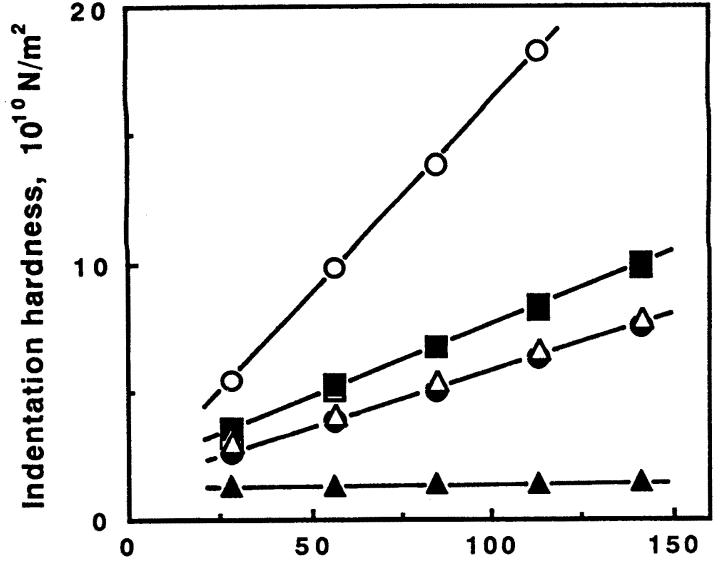

Amount of monomer in paint, phr

Fig. 1. Relationship between amount of monomer in paint and indentation hardness.

О. TMPTMA;, $1 \mathrm{G} ; \square, 2 \mathrm{G} ; \mathbf{\square}, 3 \mathrm{G} ; \triangle, 4 \mathrm{G} ; \boldsymbol{\Delta}, 9 \mathrm{G}$.

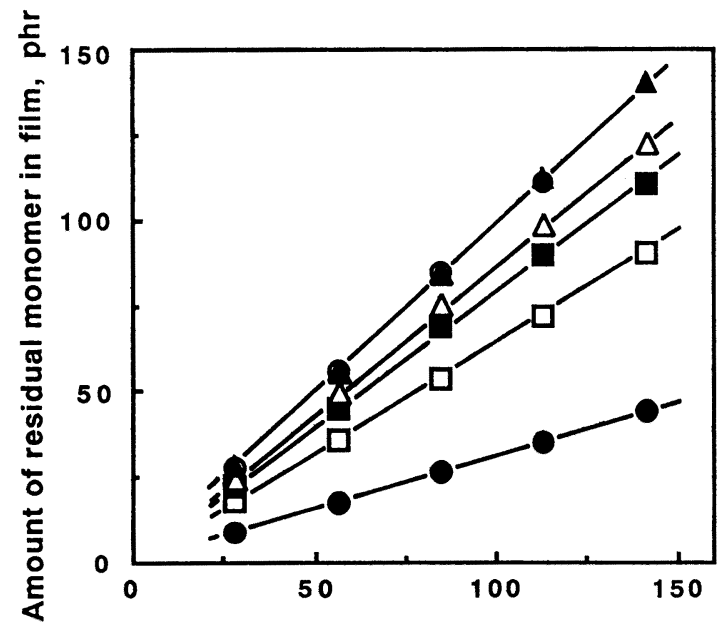

Amount of monomer in paint, phr

Fig. 2. Relationship between amount of residual monomer in film and amount of monomer in paint.

О, тмРтMA ;, $1 \mathrm{G} ; \square, 2 \mathrm{G} ; \mathbf{\square}, 3 \mathrm{G} ; \triangle, 4 \mathrm{G} ; \boldsymbol{\Delta}, 9 \mathrm{G}$.

くなるほぼ特性線の傾きが減少した。これはnGのnが小さく 分子量が低下寸るほぼ, 蒸気圧が高くなり, 塗料調整, 焼 き付け時にモノマーが蒸発して, 焼き付け塗膜中の残存モ ノマー量が減少したためと考えられる。このことはFig. $3 に$ 示すモノマーの熱重量減少曲線からも明らかである。熱重

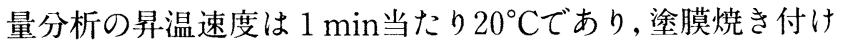
の際の昇温速度の約 10 分の 1 であることから, 塗膜焼き付 けに伴うモノマーの蒸発と等価には扱えないが,nGのnが小 さいほど重量減少量が多い傾向を示した。

Fig. 4 に塩ビ塗膜中の残存モノマー量と塩ビ鋼板の押し込 み硬度との関係を示す。この場合，塗膜中に残存したモ） マーは効率良く橋かけに関与したものと考えられ, Table 1 の二重結合当量が小さいほぼ特性線の傾きが大きくなり, 上述した考察によく対応した結果となった。

Fig. 5 に塩ビ鋼板の押し込み硬度と塩ビフィルムの破断伸 びとの関係に及ぼすモノマー種の影響を示す。破断伸びと

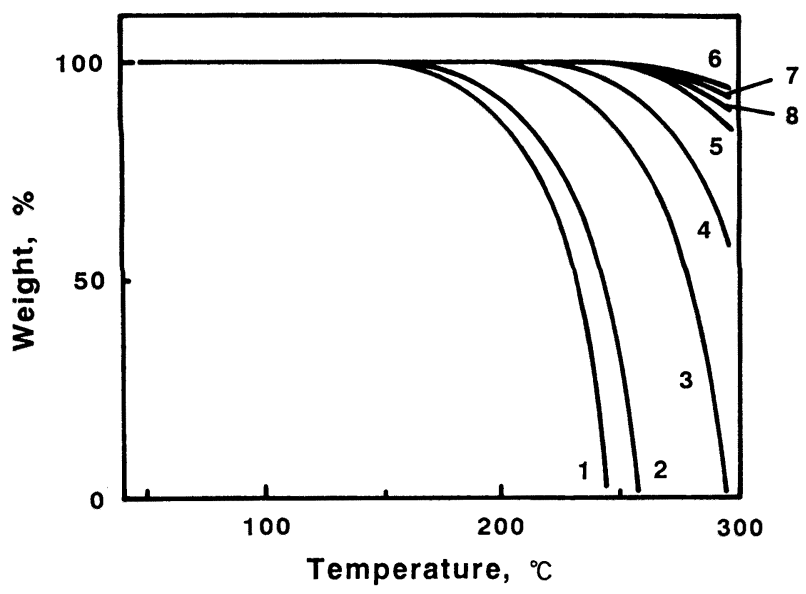

Fig. 3. TG curves of 1 , TXIB ; $2,1 \mathrm{G} ; 3,2 \mathrm{G} ; 4,3 \mathrm{G}$; $5,4 \mathrm{G} ; 6,9 \mathrm{G} ; 7$, TMPTMA ; 8 , DINP.

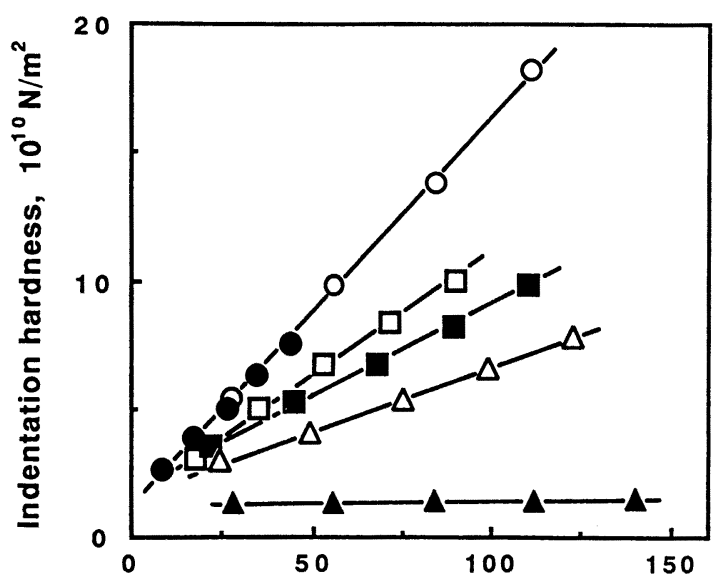

Amount of residual monomer in film, phr

Fig. 4. Relationship between amount of residual monomer in film and indentation hardness. 0 . TMPTMA;, $1 \mathrm{G} ; \square, 2 \mathrm{G} ; \mathbf{\square}, 3 \mathrm{G} ; \triangle, 4 \mathrm{G} ; \mathbf{\Delta}, 9 \mathrm{G}$.

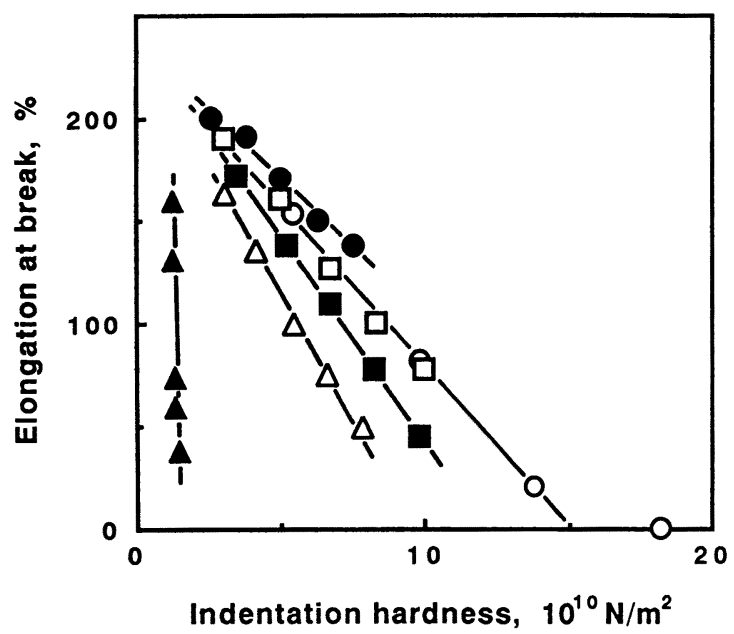

Fig. 5. Relationship between indentation hardness and elongation at break. $\mathrm{O}$, TMPTMA $\boldsymbol{\bullet}, 1 \mathrm{G} ; \square, 2 \mathrm{G} ; \mathbf{\square}, 3 \mathrm{G} ; \triangle, 4 \mathrm{G} ; \mathbf{\Delta}, 9 \mathrm{G}$.

押し込み硬度とは負の相関関係にあり，モノマーによる橋 かけによって可塑化ポリ塩化ビニルホモポリマーマトリッ クスの柔軟性が低下し, 破断伸びが減少したことが分かる。 
ここで塗膜物性としては破断伸びが大きくかつ押し込み硬 度が高いことが望ましいと言える。したがって特性線は右 下がりの傾きが小さいほぼ塗膜物性に優れると言え，1Gが 最も傾きが小さく優れた特性バランスを示した。そして三 官能型のTMPTMAは $2 \mathrm{G}$ と同程度であった。またnGにつ。 いてまとめると,nが大きくなるほぼ傾きが大きくなり特性 バランスは低下した。

ここで配合したモノマーと可塑化ポリ塩化ビニルとの相 溶性について溶解度パラメーターを用いて考察する。溶解 度パラメーターとは分子の凝集エネルギー密度の平方根で 表され，分子構造によって決定する値であり，また溶解度 パラメーターが近いと相溶しや寸いことが知られているる。 そしてこの溶解度パラメーター。はSmallによると, 下式に よって算出できる4)。

$$
\delta=\mathrm{d} \Sigma \mathrm{G} / \mathrm{M}
$$

ここでdは密度, Gはモル引力定数, Mは分子量である。Table 2 にHoyが提案した原子団 1 モル当たりの引力定数 $G^{5}$ t用 いて各々の分子構造について総和し算出したモノマーおよ び可塑䎟の溶解度パラメーターを示す。上述したように, 溶解度パラメーターが近い淁ど相溶性が高いと考兄られ， 可塑剂DINPとの溶解度パラメーターの差が小さいモノマー を配合した場合ほど，Fig. 5 において高い特性バランスを示 した。すなわちポリエチレングリコールセグメントと可塑 剛（可塑化ポリ塩化ビニル）との相溶性が低いため, 七グ メント長さが増大寸るほぼ可塑剛と相分離を起こしやすく なり, 生成したマクロな粒子あるいは不連続な相が外部応 力に対して独立に応答し, 結果としてそれらが破壊するた め6)，破断伸びが低下したと考えられる。

なおTMPTMAよりも可塑剛DINPとの溶解度パラメータ 一の差が大きい $1 \mathrm{Gが，Fig.} 5$ において最も高い特性バラン スを示したが，これは算出した溶解度パラメーターが戦密 な意味での溶解性 (分散力, 極性力, 水素結合力の各成分 項）を配慮したものでなく，また上述の式は分子量のより 小さい1Gのエントロピー効果を配慮したものでないことが 原因と考えられる。

次に，一般的な塗装鋼板の特性評価として用いられてい る鉛筆硬度, T曲げ加工について, 各々上述した押し込み硬

Table 2. Solubility parameter of monomers and plasticizer.

\begin{tabular}{cc}
\hline & solubility parameter, $10^{-3}\left(\mathrm{~J} / \mathrm{m}^{3}\right)^{0.5}$ \\
\hline TMPTMA & 17.9 \\
$1 \mathrm{G}$ & 17.6 \\
$2 \mathrm{G}$ & 18.0 \\
$3 \mathrm{G}$ & 18.5 \\
$4 \mathrm{G}$ & 18.7 \\
$9 \mathrm{G}$ & 21.1 \\
\hline DINP & 17.8 \\
\hline
\end{tabular}

DINP : Di-isononyl phthalate

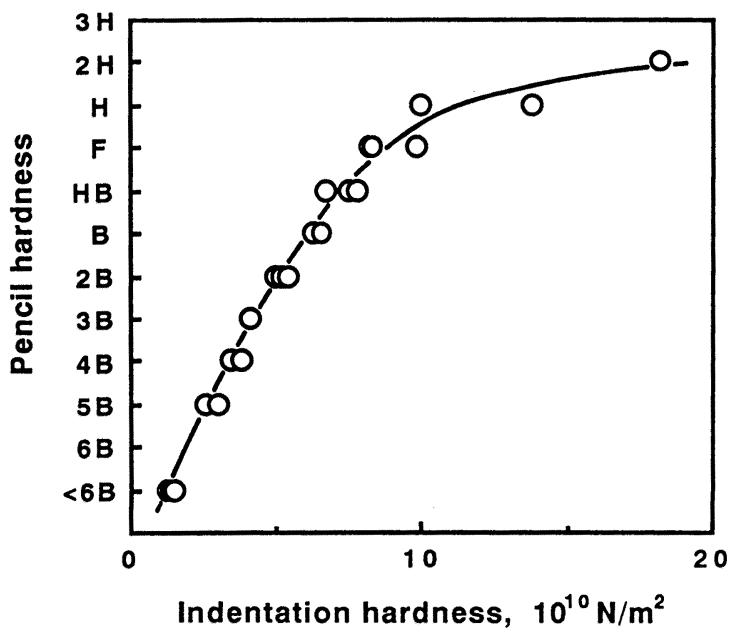

Fig. 6. Relationship between indentation hardness and pencil hardness.

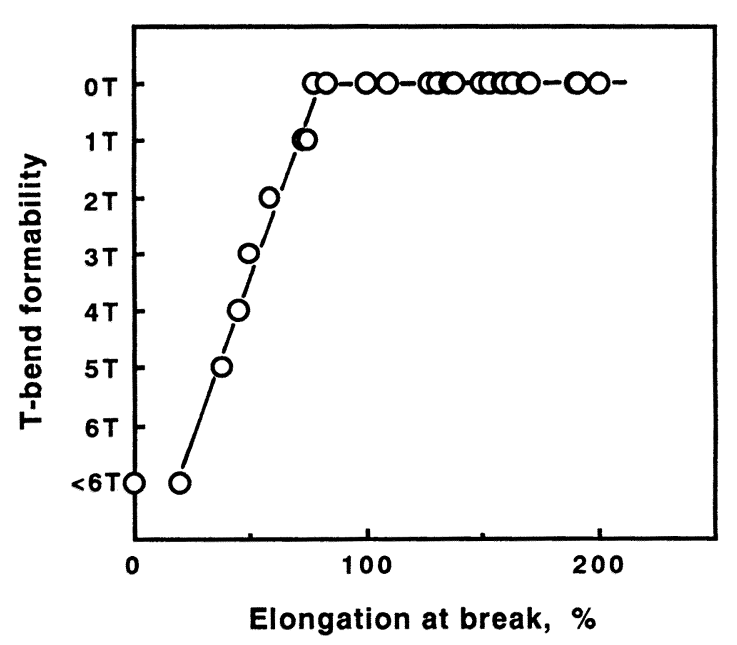

Fig. 7. Relationship between elongation at break and T-bend formability.

度ならびに破断伸びとの関係を検討した。それらをFig. 6 お よび 7 に示す。塩ビ銅板の押し込み硬度と鉛筆硬度, なら びに塩ビフィルムの破断伸びとT曲げ加工との関係には各々 良い相関性が認められ, 鉛筆硬度ならびにT曲げ加工が非連 続的な尺度であるのに対して，押し込み硬度ならびに破断 伸びによって連続的な評価ができることが分かった。また 塩ビプラスチゾルに配合するモノマー種, 配合量を調整す ることによって,塩ビ鋼板の鉛筆硬度をく6 Bから $2 \mathrm{H}$ まで 変化させることができることを見出した。

\section{$3 \cdot 2$ 電子線橋かけ反応}

電子線橋かけ塩ビ鋼板はモノマーを配合した塩ビプラス チゾルを鋼板に塗布, 焼き付けした後電子線照射して得ら れるものである。したがって通常の塩ビ鋼板と同様に焼き 付け後エンボス加工が可能であり, エンボスを有する塗装 鋼板として位置づけることができる。

上述の特性バランスを考えると,モノマーに1Gt用いた 場合が最も高い特性が得られた。しかしnGのnが小さく低分 子量であるため, モノマーの沸点が低く, 塩ビプラスチゾ 
ルへのモノマー配合量が揮発分を含めたものとなり，多く のモノマー量を要することになる。

ここでTMPTMAは比較的高い硬度・高い伸びの特性バ ランスを有し, かつ本研究で検討したモノマーの中で最も 少量で高い特性が得られた。そしてTMPTMAを50phr配合 したものでは鉛筆硬度F (押し込み硬度 $8.6 \times 10^{10} \mathrm{~N} / \mathrm{m}^{2}$ ) で あり, 0 T曲げ加工を行ってもクラックが発生しなかった(破 断伸び95\%)。この特性は, 一般的な高分子ポリエステルを 用いた加工用塗装鋼板に比べると低い特性バランスである が, 塗膜厚さが $120 \mu \mathrm{m}$ の厚膜でしかもエンボス加工が可能 である点に特徴があると言える。

ところで上述の結果はすべて電子線量が $100 \mathrm{kGy}$ 一定で得 られたものである。そこで押し込み硬度および破断伸びに 及ぼす電子線量の影響をFig. 8 に示す。押し込み硬度, 破断 伸び共に電子線量が $100 \mathrm{kGy}$ でほぼ飽和值に達した。

一方, Fig. 9 に示す塩ビ塗膜の赤外吸収スペクトルでは電 子線量が $100 \mathrm{kGy} て ゙ も$ 電子線感受性官能基であるメタクリロ イル基に帰属される吸収1640，1320，1020，820 $\mathrm{cm}^{-1}$ が認め られ，官能基レベルでの反応は完了していないことが分か る。なお電子線量を $150 \mathrm{kGy}$ に増大してもメタクリロイル基 の吸収は若干減少するが完全には消失しなかった。

これらのことはTMPTMAのメタクリロイル基が橋かけ した可塑化ポリ塩化ビニルマトリックス中に埋め込まれて7), 電子線が直接, メタクリロイル基を活性化しない限り二重 結合が開かないためと考えられる。

Fig.10にモノマーを配合していない塩ビフィルム， TMPTMAを50phr配合したフィルム,さらにこれを電子線 橋かけしたフィルムの応力ー歪曲線を示す。TMPTMAを 配合することにより，未橋かけ状態では塩ビ塗膜がかなり 柔軟となったことが分かり TMPTMAによる可塑化効果が 認められた。一方, 電子線橋かけしたフィルムでは著しく 剛性が増大したことが分かる。ここで歪を掛け始めた直後

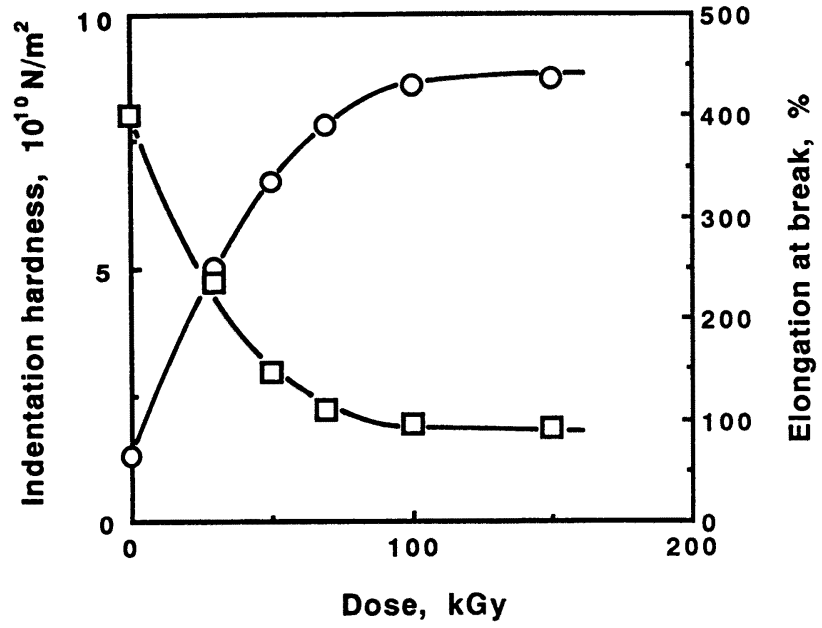

Fig. 8. Dose vs. indentation hardness and elongation at break.

$\bigcirc$, indentation hardness; $\square$, elongation at break.
に応力が著しく増大した原因として，TMPTMAによる高 密度の橋かけ効果が考えられるが，TMPTMA成分が可塑 化ポリ塩化ビニルと相分離して, 独立して歪に対応したこ とも推察される。

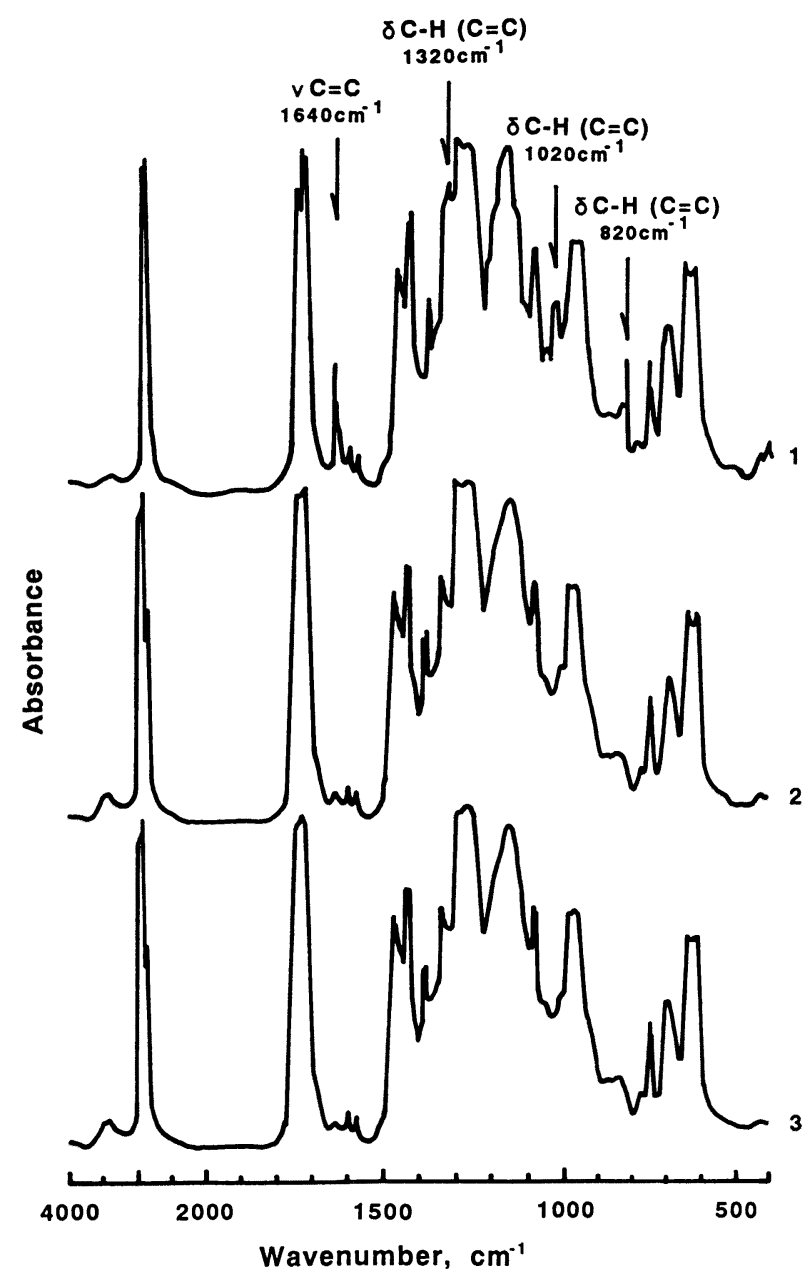

Fig. 9. Change of infrared spectra for PVC films containing 50phr TMPTMA by EB irradiation and dose.

1, unirradiated; 2, 100kGy ; 3, 150kGy.

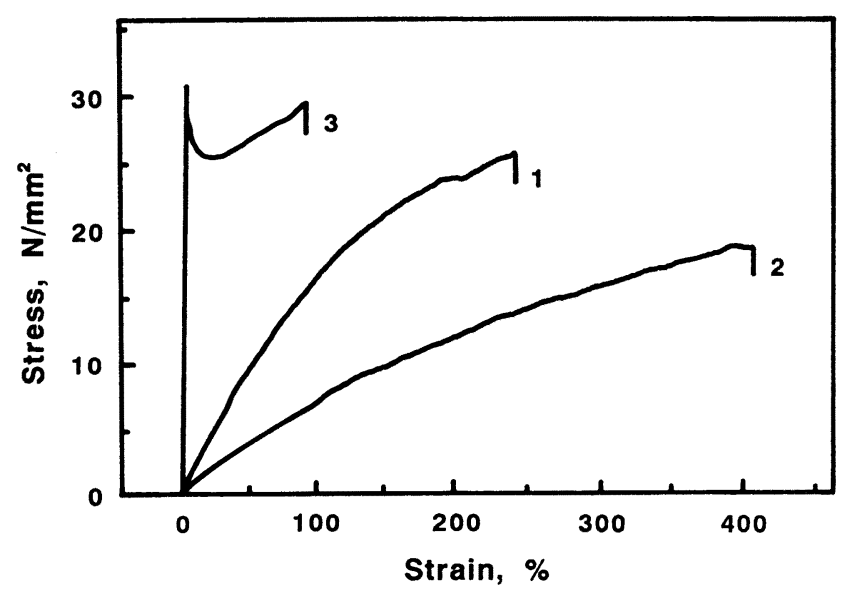

Fig. 10. Stress-strain curves of 1 , control PVC film; 2, unirradiated PVC film containing $50 \mathrm{phr}$ TMPTMA; 3, EB-irradiated PVC film containing 50phr TMPTMA. 


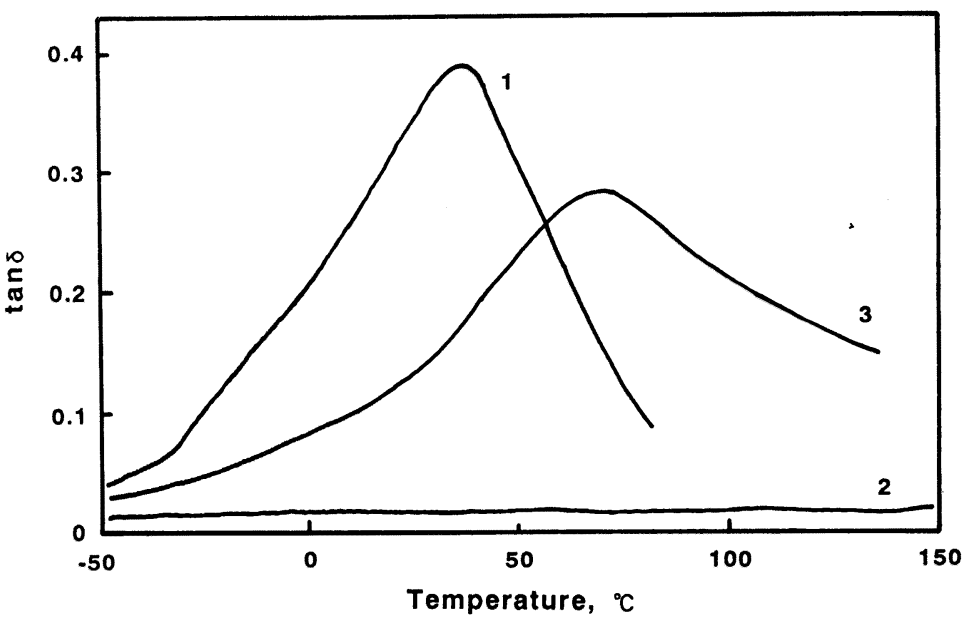

Fig.11. Effects of temperature on $\tan \delta$. 1, control PVC film; 2, EB-cured TMPTMA; 3,EBirradiated PVC film containing 50phr TMPTMA.

Fig.11にモノマーを配合していない塩ビフィルム， TMPTMA電子線硬化膜（塗膜厚さ $50 \mu \mathrm{m}$, 電子線量 100 kGy) およびTMPTMAを50phr配合し電子線橋かけした塩

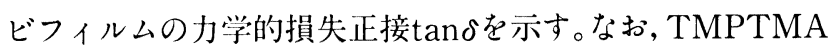
を配合した電子線橋かけ前の塩ビフィルムはフィルムの剛 性が低すぎて測定不能であった。モノマーを配合していな

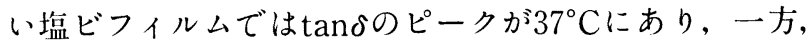

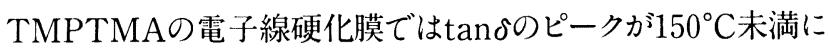
見られなかった。そして電子線橋かけ塩ビフィルムの $\tan \delta$

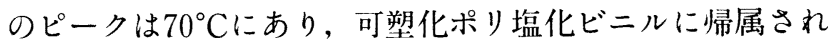

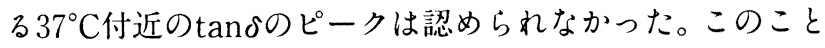
はTMPTMAが可塑化ポリ塩化ビニルマトリックス中でホ モポリマーを形成しているのではなく，効率良く可塑化ポ リ塩化ビニルを橋かけしていることを示唆していると言え る。

ところで，この電子線橋かけ塩ビ鋼板の油性マーキング ペンによる污染度は42であり，モノマーを配合していない 塩ビ鋼板が50であることに对して，耐污染性はほとんど変 わらなかったと言える。これは油性マーキングペンによる 污染が可塑剤へのマーキング染料の移行, さらに塗膜内部 への拡散によって起こることを考える8)と, ポリ塩化ビニル ホモポリマーの橋かけ間分子量, 言い換えれば橋かけの網 目の大きさが可塑剤DINP(分子量413) 分子に比べて十分に 大きいことを示すものと言える。しかしポリ塩化ビニルホ モポリマーにTMPTMAが寸べてモノマー単位で橋かけし ていると仮定すると，すなわち塩化ビニル単位10.8に対し てTMPTMAが 1 分子存在し, ポリ塩化ビニルセグメント が 3 筒所( 3 官能)で橋かけされ，2 分されると仮定すると 橋かけ間分子量は約 340 となる。このことは上述の仮定が適 当でないことを示しており,そしてTMPTMAはポリ塩化 ビニルホモポリマーとの橋かけ反応以外に，ホモ重合なら びにポリ塩化ビニルホモポリマーにグラフト重合している ことが推察される。

以上のことをまとめると, TMPTMAはポリ塩化ビニル ホモポリマーを高密度に橋かけし, 可塑化ポリ塩化ビニル
ホモポリマーの運動性を束縛することによってマトリック スの剛性が増大したと考えられる。またTMPTMAはモ， マー単位でのポリ塩化ビニルホモポリマーの橋かけだけで なく、ホモ重合ならびにポリ塩化ビニルホモポリマーへの グラフト重合にも関与していると考えられ，この部位はは とんぞ橋かけに寄与せず，可塑剤と相溶したドメインを形 成していると推察される。

\section{4. 結言}

塩ビプラスチゾルにモノマーを配合して電子線橋かけし， 得られた塩ビ鋼板に関して，塗膜硬度と曲げ加工性との関 倸に及ぼすモノマー種の影響について検討した。さらに電 子線橋かけ反応に関して検討を加え，次の結論を得た。

1 )塩ビ鋼板の塗膜硬度は焼き付け後の塗膜中に残存した モノマー量が多くなるほぼ増大し，二重結合当量が小さい モノマーほE゙少量のモノマー量で高い塗膜硬度が得られた。

2 ) 塩ビ鋼板の塗膜硬度と曲げ加工性とのバランスはモ， マー種に依存し, 可塑剤との溶解度パラメーターの差が小 さいモノマーほぼ，モノマーと可塑化ポリ塩化ビニルとの 相溶性が高く，高い特性バランスを示した。そしてTMPTMA を50phr配合し電子線橋かけした塩ビ鋼板では, 鉛筆硬度F, 0 T曲げ加工ノークラックの塗膜特性が得られた。

3 ) TMPTMAを配合した電子線橋かけ塩ビ塗膜は動的粘 弾性挙動から, 可塑化ポリ塩化ビニルとTMPTMAがミク ロなレベルで相溶しており，TMPTMAによる高密度の橋 かけによって剛性が付与できたことが分かった。

\section{文献}

1）坂本良憲：実務者のための電子線加工，(1989), [高分子刊行会]

2) JIS Z8730-1980 (色差表示方法)

3）金丸 競：接着と接着剤，(1969), [大日本図書]

4) P. Small : J. Appl. Chem., 3 (1953), p.71

5) K. L. Hoy : J. Paint Technol., 42 (1970), p.76

6) 上田二士, 門永政雄：高分子化学, 23 (1966), p.165

7 ）森 浩治, 興石謙二, 增原憲一：高分子論文集, 48 (1991), p.1

8）森 浩治，興石謙二，增原憲一：高分子論文集, 48 (1991), p.555 